\title{
The Concept of Phenomenology in Fichte's Wissenschaftslehre of 1804/II
}

Claude Piché, Université de Montréal

This is a working copy (preprint): it may differ from the final published version and should not be quoted nor referenced. The final version was published in Fichte and the Phenomenological Tradition, V. Waibel, D. Breazeale and T. Rockmore (eds.), Berlin /New York, De Gruyter, 2010, p. 25-40.

II existe une version FRANÇAISE de ce texte qui a été déposée ici sur Papyrus.

\begin{abstract}
Fichte characterizes the second part of his Doctrine of Science of 1804 with the term « phenomenology ", to which he assigns a double meaning : theory of illusion (Schein) and theory of phenomenon (Erscheinung). If the first part of this definition reminds us of Lambert, the inventor of phenomenology as a philosophical discipline, the second part corresponds to the idea that Kant has of this discipline, for instance in the Metaphysical Foundations of Natural Science. Now the question is: is it possible to integrate into a single discipline two concepts as different as Schein and Erscheinung? If Fichte is successful in uniting both concepts in his phenomenology, it might be due to the fact that he follows in this the path already opened by Reinhold in his Beyträge of 1802-1803.
\end{abstract}

KEYWORDS : Fichte, Reinhold, Kant, Lambert, phenomenology, illusion, appearance

The topic of this presentation is the concept of phenomenology as we find it in Fichte's Doctrine of Science of 1804. I refer here to the second series of lectures given during that year, between April 16 and June 8. ${ }^{1}$ I do not want to go into the concrete details of this phenomenology, since it represents the second part of an undertaking that is extraordinarily dense and speculative. As we know, the 1804 Wissenschaftslehre is composed of two main parts, the first being a theory of truth, or what we could call an alethology, ${ }^{2}$ as the counterpart of phenomenology. It consists of an ascending movement, whereby the pure "insight" (Einsicht) gives access to the absolute, and of a descending movement, from the absolute back to the phenomena. Taken together, these two movements make up a complete exposition of Fichte's philosophia prima. In fact, this version of the Wissenschaftslehre has a special status within the

\footnotetext{
${ }^{1}$ For an account of the circumsatnces under which these lectures were held, see Reinhard Lauth, "Über Fichtes Lehrtätigkeit in Berlin von Mitte 1799 bis Anfang 1805 und seine Zuhörerschaft,“ Vernünftige Durchdringung der Wirklichkeit. Fichte und sein Umkreis (Neuried: Ars una, 1994), pp. 191-232.

${ }^{2}$ Jean-Christophe Goddard, Fichte (1801-1813). L'émancipation philosophique (Paris : PUF, 2003), p. 39.
} 
Fichtean corpus since it is "one of the most accomplished texts", that he has left us, and because it announces the further developments of the doctrine of science.

The reason why it might be helpful here to concentrate primarily on the concept of phenomenology is that it deserves particular attention due to a certain ambiguity in the formulation of its definition. Therefore, understanding the correct articulation of the two elements included in this concept may be rewarding. In lecture 13, Fichte defines phenomenology as a "theory of phenomenon and of appearance". 4 The question is then: how is the word "and" to be read here? Does it mean "or in other words" or does it link two different things, namely phenomenon and appearance? One might be tempted to opt for the first reading of the definition of phenomenology if we compare it with the twofold definition given by Fichte in the first part of his lectures: the Seynslehre is a "theory of reason and of truth". 5 Here, in contrast with the definition of phenomenology, we suspect no opposition between reason and truth, whereas phenomenon (Erscheinung) and appearance (Schein) have very different meanings. A phenomenon can be considered as something that is neutral with respect to its propensity to lead to truth or falsehood. On the other hand, the German word Schein (translated henceforth by the word "appearance") bears the sense of an illusion and the possibility of deception. Thus, I think that we might be well advised to maintain a clear distinction between the two elements of Fichte's idea of phenomenology and to opt for the second reading. His concept is a complex one and, as we will see, there are good reasons for this.

In what follows, I would like to proceed to a historical survey of Fichte's forerunners in the philosophical use of the term phenomenology. The fact is that Fichte does not quote his sources in this matter and it is not altogether clear from whom he has borrowed his concept of phenomenology. One thing is certain, however: The history of the term phenomenology as used to designate a philosophical discipline goes back 40 years. Johann Heinrich Lambert employs it for the first time in his Neues Organon in 1764. We later find it in Kant's Metaphysische Anfangsgründe der Naturwissenschaft (1786) and then in Reinhold's Beyträge zur leichtern Uebersicht des Zustandes der Philosophie am Anfang des 19. Jahrhunderts., more precisely in

\footnotetext{
${ }^{3}$ Miklos Vetö, Fichte. De l'Action à l'Image (Paris : L'Harmattan, 2001), p. 102.

${ }^{4}$ Fichte, Die Wissenschaftslehre. Zweiter Vortrag im Jahre 1804 (quoted hereafter WL 1804/II), ed. R. Lauth and J. Widmann (Hamburg: Meiner, 1986), p. 138. (all translations are my own).

${ }^{5}$ Fichte, WL 1804/II, pp. 150-151.
} 
the fourth issue (1802) of this series of contributions. To be sure, the meaning of the term phenomenology varies considerably according to the philosophical context in which it is used. Therefore, the perspective I shall adopt here will be a more or less formal one. We will study the semantic content of this concept through its short history solely in order to draw structural analogies; otherwise we would lose sight of the uniqueness of Fichte's project in the Wissenschaftslehre of 1804. In fact, phenomenology is associated here with the externalisation of absolute being: In the second part of his lecture course, Fichte aims at tracing the genesis of phenomena as part of the manifestation of the absolute in order to prevent their being mistaken for ontologically independent objects and becoming, therefore, false appearance.

Fichte's definition of phenomenology is composite insofar as it unites two elements that can be treated independently from one another. And this is precisely the case if we consider the use of this concept found in Lambert and the one found in Kant. For the former, phenomenology deals exclusively with appearance, while for the latter it deals with phenomena.

In Lambert's Neues Organon, the word 'phenomenology' is used to designate the fourth and last part of the book. Lambert is considered to be the inventor of phenomenology as a philosophical discipline, and we must take notice of the fact that at first this discipline was designed to deal with illusion and delusion. The subtitle of the fourth part of his book corresponds to one of the two components of Fichte's definition: "Lehre von dem Schein"- Fichte writes Scheinlehre -- and there is no doubt, according to the definition found in the foreword to Lambert's whole work, that it is a theory elaborated in order to prevent appearance from leading the knowing subject into error: "Finally Phenomenology, or the theory of appearance, is the fourth [science] and has to single out appearance and provide the means to avoid it and to create our way [durchdringen] to truth". ${ }^{6}$ The word Schein, which is at the center of this definition, clearly has a negative accent, as opposed to the more neutral term Erscheinung (phenomenon), which Lambert does not use in his phenomenology as a technical term. Appearance is conceived as a serious obstacle in the search for truth. Its role is stated in the following passage, taken from $\S 1$ of the Phenomenology: "[Appearance] very often leads [us] to represent to ourselves the things in another form, and to easily take what they appear to be for what they really are, or to

\footnotetext{
${ }^{6}$ Johann Heinrich Lambert,"Vorrede," Neues Organon, in Philosophische Schriften I, ed. H.-W. Arndt (Hildesheim : Olms, 1965), not paginated.
} 
confuse [reality] with [appearance]."7 According to Lambert, it is "always a mistake" ${ }^{\text {" }}$ to take the appearance for the thing itself, for the thing as it is in reality. Nevertheless, the mere appearance of things, when it is unmasked and recognized as such, may become an incentive to the search for truth and lead to the discovery of the real nature of things. As a model for the phenomenological project, Lambert refers to the way an astronomer proceeds. For example, if an astronomer observes a certain movement of the stars, he might suspect this movement to be a mere appearance, and can take it as a starting point in order to search for the hidden laws of this movement. In the end, he might even come to the conclusion that it is the spectator and the earth under his feet that are moving, and not the stars.

Let us now turn to Kant. We know that he was familiar with the Neues organon, to which he occasionally refers, especially in his lectures on logic. ${ }^{9}$ In view of this fact, it is all the more interesting to note that in his Metaphysical Foundations of Natural Science from 1786 he presents a definition of phenomenology that is not only different from the Lambertian conception, but that moreover seems to be stated in direct opposition to Lambert. Kant conceives phenomenology as a theory of phenomena (Erscheinungen), or more precisely as a theory that explains how phenomena become experience. I do not intend to go into the details of the specific form of phenomenology developed in the fourth part of Kant's book. It might suffice to point out that it deals with the movement of bodies from the standpoint of the categories of modality. This means that the phenomena in this case are material ones and that the concept of experience is considered not in the context of transcendental philosophy, but rather of the metaphysics of nature. But this specific use of the term here does not matter too much, since what Kant has to say about the difference between Erscheinung and Schein holds for the "whole" of philosophy.

Kant argues that it is of the utmost importance to distinguish Erscheinung from Schein, because Schein as opposed to Erscheinung already implies a judgment. And in this case the judgment might very well lie on subjective grounds instead of objective ones. Involving as such no judgment, the Erscheinung is not exposed to such a "danger". It is still neutral, so to speak, with regard to truth or falsehood.

\footnotetext{
${ }^{7}$ Lambert, Neues Organon, Philos. Schriften II, pp. 217-218.

${ }^{8}$ Lambert, "Vorrede," Neues Organon, Philos. Schriften I, not paginated.

${ }^{9}$ Kant, Logik (Jäsche), in Gesammelte Schriften, Akademie Ausgabe (quoted hereafter Ak.), Book IX (Berlin: de Gruyter, 1968), p. 21.
} 
What is in question here is not the transformation of appearance [Schein] into truth, but rather of phenomenon [Erscheinung] into experience; because in appearance the understanding with its judgment determining the object is always involved, even though it runs the risk of taking the subjective for the objective; in the phenomenon no judgment at all from the understanding is involved. This remark is useful not only here but for philosophy as a whole, since otherwise, when dealing with phenomena we take this expression as having the same meaning as appearance, we always expose ourselves to misunderstanding. ${ }^{10}$

This explicit warning seems to be directed at those, like Lambert, who would be tempted to confuse Kant's conception of the phenomena with mere appearances. For the reader of the first edition of the Critique of Pure Reason, this warning sounds familiar. For instance, at the beginning of the Transcendental Dialectic, Kant makes this point in similar terms: appearance involves a certain claim to truth, whereas the phenomenon, critically understood, does not involve any such claim. ${ }^{11}$ Erscheinung in fact is a term that is introduced in the Transcendental Aesthetic, that is, prior to dealing with the role of concepts and judgments in knowledge. But even at this early stage, the reader might be tempted, with regard to the distinction between phenomenon and thing in itself, to declare the phenomenon to be mere illusion deprived of any reality; which is another case of the confusion between Erscheinung and Schein, as Kant indicates. ${ }^{12}$ Kant's other remark, made this time in the Aesthetic, was provoked by the objection brought up by "men of intelligence" such as Mendelssohn and Sulzer. But it might be relevant to note that Lambert (who died in 1777) was also among those who had voiced this objection, because he could not help but interpret Kant's Erscheinung in terms of his own concept of Schein. The fact that, in Kant, time is considered as a mere Erscheinung means for Lambert that the whole of experience and the changes taking place in it are nothing more than pure illusion. ${ }^{13}$

With Lambert and Kant, we are facing two very different conceptions of phenomenology and, at first glance, it is not clear how these conceptions could be reconciled or, moreover, combined into a coherent one, as will be the case in Fichte's Wissenschaftslehre of 1804/II. For instance, Kant does not even think of using the word phenomenology in his Critique of Pure

\footnotetext{
${ }^{10}$ Kant, Metaphysische Anfangsgründe der Naturwissenschaft, Ak. IV: 555.

${ }^{11}$ Kant, Kritik der reinen Vernunft, A 293/B 349-350.

${ }^{12}$ Kant, Kritik der reinen Vernunft, A 36/B 53.

${ }^{13}$ See Lambert's letter to Kant of October 13, 1770, Ak. X : 103-111. In the immediate aftermath of his Dissertation of 1770, Kant defined the positive part of this work as a phaenomenologia genaralis. See his letter to Lambert of
} September 2, 1770, Ak. X : 98. I have treated this question in my article "Kant, heredero del metodo fenomenológico de Lambert,” trans. J. Rivera de Rosales, Endoxa (Madrid), No. 18, 2004, pp. 45-68. 
Reason to designate his theory of phenomenon in the Transcendental Aesthetic, in all likelihood because he feared spreading confusion in the minds of readers acquainted with Lambert's definition. On the other hand, and for the same reason, it is out of the question for him to use this expression to characterize his own "logic of appearance" because of the confusion caused by the etymology of the word 'phenomeno-logy' itself. This is precisely the ambiguity he wants to prevent, so he chose for his theory of transcendental illusion in the first Critique the classical term "dialectic".

But before Fichte, it is Reinhold, in his phenomenology of 1802, who undertakes to combine both meanings. In fact, he is the first to use the term phenomenology in the title of a philosophical work: Elemente der Phänomenologie oder Erläuterung des rationalen Realismus durch seine Anwendung auf die Erscheinungen. ${ }^{14}$ In the Vorbericht to this work he gives a precise definition of the new understanding of the term: "[Phenomenology] completes the exposition of rational realism through the application of its principles to the phenomena, which it teaches us, with the help of these principles, to distinguish and separate from mere appearance."15 Firstly, we find in this definition a move that reminds us of Lambert: in our knowledge, appearance must be identified as such and we must find the means to get rid of its spurious aspects. But there is, secondly, a Kantian element in this conception, in that the phenomenon serves as the basis of every appearance. We understand now the need felt by Kant to distinguish carefully between Erscheinung and Schein. The confusion is easily arrived at. But it is nevertheless the case that the theory of appearance presupposes, at least here according to Reinhold, a well-founded theory of phenomena, because appearance is nothing other than a misinterpreted phenomenon. The illusion occurs when the phenomenon is taken for more than what it is in reality, i.e., when the Erscheinung is mixed up "with the essential being, with the archetype" of all things. ${ }^{16}$ If, on the other hand, we consider the matter closely, we realize that Fichte's conception of the problem of false appearance is in full agreement with that of Reinhold.

\footnotetext{
${ }^{14}$ Karl Leonhard Reinhold, Beyträge zur leichtern Uebersicht des Zustandes der Philosophie beym Anfang des 19. Jahrhunderts, Heft IV (Hamburg: Friedrich Perthes, 1802), p. 104.

${ }^{15}$ Reinhold, Beyträge, Heft IV, p. IV.

${ }^{16}$ Reinhold, Beyträge, Heft IV, pp. 108, 155. See also Beyträge, Heft VI (1803), pp. 69-70. I have tried to show what Reinhold's concept of phenomenology owes to Kant, and in particular to the Transcendental Dialectic, in "Der Phänomenologiebegriff bei Kant und Reinhold,“ K. L. Reinhold. Am Vorhof des Idealismus, ed. P. Valenza (Pisa and Rome: Instituti editoriali e poligrafici internazionali, 2006), pp. 59-72.
} 
It is also the case for Fichte that appearance occurs when the phenomenon is "taken for the essence itself." "This common conception of the articulation of Erscheinung and Schein at the basis of their respective phenomenologies, however, is not the only thing over which they agree. There are also striking similarities between both philosophical projects and they are significant enough to be taken into consideration. It might suffice here to mention three of them, leaving aside momentarily the question of the possible influence of Reinhold's phenomenology of 1802 on Fichte's Wissenschaftslehre of 1804.

The first point worthy of mention concerns their views of the philosophical system. In both cases we find a twofold structure of the system. In Reinhold, rational realism consists of an ontology and of a phenomenology. The former deals with the essence of things as such, and it is made possible through the new approach set forward by Bardili: "thinking as thinking" (Denken als Denken), which is the only appropriate theoretical channel to gain access to the essence of things. The latter, phenomenology, elaborates, as we have read in the extensive title of this part of the system, an "application" of the results of the ontology to the phenomena. These phenomena are the elements of the sensible world, so that Reinhold's phenomenology has to be understood as a philosophical discourse on nature, as a "pure philosophy of nature". ${ }^{18}$ Because the phenomena are thematized according to the ontological principles arrived at in the first part of the system, they do not run the risk of being taken for the "objects themselves" (Objekte selbst), but grasped strictly as what they are: phenomena. Taken together, these phenomena are involved in the "manifestation of the originary being [Urwesen] in the essence of things," simply, they contribute, as a mere "condition, $" 20$ to the "manifestation of God in nature". ${ }^{21}$ From here, it is quite easy to draw a parallel with Fichte's Wissenschaftslehre, since we already know that the lectures of 1804 to which we are referring contain an ascending and a descending movement. In the first part, we are led from the multiplicity of things in the world to an insight into the one absolute being as such, while the second part exposes the manifestation of pure being through a multiplicity that is composed of what now has to be considered as mere phenomena.

\footnotetext{
${ }^{17}$ Fichte, WL 1804/II, p. 115.

${ }^{18}$ Reinhold, Beyträge, Heft IV, p. 110.

${ }^{19}$ Reinhold, Beyträge, Heft IV, pp. 104, 132.

${ }^{20}$ Reinhold, Beyträge, Heft IV, p. 108.

${ }^{21}$ Reinhold, Beyträge, Heft IV, p. 106.
} 
This is to say that the phenomenology developed in the second part has to produce the "deduction (of the diversity of phenomenal reality)",22 which means that the world as we know it now has to be envisaged as the "phenomenon of the one true existent".

The second similarity to which I would like to draw attention concerns the status of appearance. It is clear that Reinhold in his Beyträge as well as Fichte in his 1804 lectures deal extensively with the different philosophical systems in their historical forms. Specifically, they both take a very strong stand toward the systems of their contemporaries. But in this they have one point in common: they do not limit themselves to denouncing the false appearances present in the philosophical discourse of their opponents, for the simple reason that the problem of truth or falsehood is not just a matter of philosophical science, but also a problem for mankind in general. If their respective phenomenologies are to have universal reach, they have to show to what extent illusion and deception are facts that are not confined to classical systems. This is the reason why they both try to show how the mistakes found in highly technical metaphysical theories have their origins in everyday knowledge. The philosophical mistakes are just the consequences of a Schein already at work in ordinary knowledge.

For example, Fichte criticizes realism and idealism as two unilateral philosophical positions which share the same prejudice in that they each in their own way claim to have access to the truth of things. As two diametrically opposed philosophical systems, both of them are refuted in the Wissenschaftslehre. But in order to refute them, the doctrine of science has to trace their origins -- and the force of the illusion that they carry -- in everyday knowledge. Therefore, the Wissenschaftslehre has to deal with
the natural idealism and realism that stem, without our conscious intervention, from ordinary knowledge, at least in its derived occurrences and phenomena... It is also the goal of the Doctrine of Science to deduce [idealism and realism] as entirely natural and spontaneous disjunctions and unilateralities of ordinary knowledge. ${ }^{24}$

If we now turn to Reinhold, we can notice a similar attitude toward the origin of falsehood in philosophy. For Reinhold, the ultimate appearance in philosophy lies in the duality between subjectivity and objectivity and in the fact that they have come to be considered identical. It goes without saying that, in his eyes, Schelling's system of identity is the most perfect expression of

\footnotetext{
${ }^{22}$ Fichte, WL 1804/II, p. 89.

${ }^{23}$ Fichte, WL 1804/II, p. 90.

${ }^{24}$ Fichte, WL 1804/II, p. 118
} 
this fatal mistake, which is nevertheless already at work in ordinary knowledge. Let us read the very first words of Reinhold's text on phenomenology:

The error which is contained in every other error and under which every other error is contained, lays... precisely in the appearance of the objectivity of the subjective, and of the subjectivity of the objective, which is held for the truth itself. This appearance, which according to its essence is one and the same in the common and in the speculative error, takes moreover in the latter case the appearance of an elevation above itself. $^{25}$

To be sure, we also find a criticism of the dual structure of subjectivity/objectivity ${ }^{26}$ in the Wissenschaftslehre of 1804, a criticism that Fichte pursues in his own terms. But more interesting here is their common concern to show that, beyond philosophical speculation, there is a certain kind of diffuse dogmatism that makes the ordinary person think that he or she is in presence of the things themselves. No wonder then that Fichte claims that almost all of mankind lives in the "world of error". ${ }^{27}$ It is precisely the role of phenomenology to remind us that this world consists of mere phenomena and that they must be regarded as such.

The third point these authors have in common concerns what has come to be characterised as the philosophy of subjectivity. It is clear that Reinhold in his Beyträge stigmatizes Fichte's Wissenschaftslehre for being the quintessence of a philosophy based on the subject. And Fichte for his part is certainly authorized to claim that this accusation does not bear upon the Doctrine of Science, even at the time of its first inception in Jena. But be it as it may, the fact is that Reinhold, from 1800 on, not only turns his back on his Elementarphilosophie, among other things, but that he criticizes this earlier position systematically. We know that the Elementarphilosophie was based on a first principle that Reinhold designated as the "principle of representation" or as the "principle of consciousness". Both terms, representation and consciousness, refer to modern philosophy insofar as it is considered to be a philosophy of subjectivity. But now in his phenomenology, Reinhold, while not dismissing representation outright, does place it in the proper perspective in view of his new allegiance to rational realism. And the same goes for Fichte, who stigmatizes consciousness, envisaged as the ultimate ground of truth.

\footnotetext{
${ }^{25}$ Reinhold, Beyträge, Heft IV, p. III.

${ }^{26}$ Fichte, WL 1804/II, pp. 24-25, 45.

${ }^{27}$ Fichte, WL 1804/II, p. 75.
} 
In his Beyträge, Reinhold relativizes the status of representation in that it is, from then on in his work, limited to the field of phenomenology as opposed to ontology. Ontology has access to the object "in itself" while phenomenology can only disclose it as representation. In other words, representation is henceforth restricted to the realm of phenomena.

The object of representation... as such, the represented, or the object as represented, is the phenomenon, and as the phenomenon, which is not a contradiction, which is therefore no mere appearance, it is as such in reality $[$ Wirklichkeit $]{ }^{28}$

As long as representation is restricted in its scope and limited to the correctly interpreted phenomena, there are no risks of delusion. In comparison, Fichte's position toward consciousness is quite similar. Consciousness certainly continues to play an all-important role in knowledge and the Wissenschaftslehre no doubt intends to describe it. The problem is, though, that one might be tempted to confer upon immediate consciousness the function of a foundation of knowledge, in which case it becomes nothing more than "vain appearance and error":

... the ground of truth as truth certainly does not lay in consciousness, but rather directly in truth itself... [consciousness] remains only the outer phenomenon of truth... whose ground still has to be given to you. But if you think that in this consciousness lays the ground for truth to be truth, then you fall under the spell of appearance. ${ }^{29}$

As we can see, consciousness itself is, in light of the absolute, a mere phenomenon, and it is consequently evident that it cannot serve as the ground for the truth of being.

The three points that I have just stressed are intended to show analogies between the Reinholdian and the Fichtean conceptions of phenomenology: 1- the phenomenal world as a manifestation of the absolute, 2- the natural illusion present in ordinary knowledge as the condition of philosophical appearance and 3- the critique of the philosophy of subjectivity. It goes without saying that both phenomenologies belong to philosophical systems that are appreciably different, and that we can not speak with certainty of an influence on Fichte of Reinhold's texts published in the Beyträge between 1801 and 1803. In fact, Fichte does not acknowledge any dept toward Reinhold in his Wissenschaftslehre of 1804 . When mentioned, the name of Reinhold is an object of criticism. Jean-François Goubet, in an interesting article entitled "Fichte's Phenomenology in the WL-1804/II: a Historical Approach" has devoted his research to

\footnotetext{
${ }^{28}$ Reinhold, Beyträge, Heft VI, p. 69.

${ }^{29}$ Fichte, WL 1804/II, p. 137.
} 
this problem, and he himself admits that he could not arrive at anything conclusive. ${ }^{30}$ The only thing we know is that Fichte had read the first issues of the Beyträge, but we do not know exactly about the fourth issue, the one that contains the phenomenology. In a letter to Bardili from November 21, 1803, Reinhold writes that he has sent Fichte the sixth issue of his Beyträge, and in a letter dating from the same period to Friedrich Christian Perthes, Fichte acknowledges the reception of Reinhold's "writings" -- in plural --, which leads the editors of the $G A$ to conjecture that he received the fifth together with the sixth issue. ${ }^{31}$ But no conclusion can be drawn from the simple fact that he was in possession of these issues dealing abundantly with Erscheinung and Schein.

Before coming to my conclusion, it might be useful to focus on Fichte's phenomenology for its own sake and to briefly sketch its status within the economy of the 1804 Wissenschaftslehre. If the first part of the lectures is a long ascending path toward truth, it does not mean that the second, descending part brings us back to the realm of illusion. In other words, the fact that the "theory of truth" of the first part is followed in the second by a "theory of appearance [Schein]" does not mean that the latter contains only a theory of deception. We have come to realize that the Erscheinungslehre - also constitutive of the second part -- does not mean the same as Scheinlehre, so that the phenomenology laid out in the second part is intended to provide a positive appraisal of the phenomenal world.

The first part can be called a 'theory of being' insofar as it aims at reaching being as such, as pure life, in its total autarchy. Being remains therefore within (in) itself, it exists from (von) itself and through (durch) itself. ${ }^{32}$ In the first part of the Wissenschaftslehre we therefore witness the "self-construction of being," 33 which brings us to an absolute knowledge of being. Now, this knowledge of being is not separated from being as such; rather, it takes part in it. This is why Fichte in his Berlin lectures tries to guide his audience to what he calls pure Einsicht, the insight through which a person raises his/herself to the level of this knowledge, a knowledge from within, momentarily leaving aside any external point of view. Such an external standpoint is

\footnotetext{
${ }^{30}$ Jean-François Goubet, "La phénoménologie de Fichte dans la WL-1804/II: une approche historique," in Fichte.

La doctrine de la science de 1804, ed. J.-C. Goddard and A. Schnell (Paris: Vrin), forthcoming.

${ }^{31}$ For the two letters and the note of the editors, see GA III/5: 5.

${ }^{32}$ Fichte, WL 1804/II, p. 151.

${ }^{33}$ Fichte, WL 1804/II, pp. 161-162.
} 
represented by consciousness. Undoubtedly, consciousness is always present in knowledge and is in a certain way inescapable, but nevertheless the audience is asked to "abstract" from it, ${ }^{34}$ because, as we already know, immediate consciousness has a tendency to objectivise everything, to put it at distance, before itself, in a way that blurs the true origin of the object, its genesis. In other words, the object of consciousness is the result of a projection, of a "proiectio per hiatum irrationalem" 35 as Fichte puts it. Consciousness is always content with mere Fakta, while the aim of the Wissenschaftslehre has always been to trace the genesis of these Fakta.

In view of this, the task of phenomenology, as the descending movement of the Wissenschaftslehre, is to reintroduce consciousness in the limited scope of its legitimate functions. Reintroducing consciousness means at the same time reintegrating all the elements that had been left aside in the first part in order to gain access to the truth of pure being. In this manner, the phenomena, as objects of consciousness, are taken into account, but only for what they are in truth, i.e., mere phenomena of the absolute and not some kind of independent reality endowed with an autonomous existence. Phenomenology is therefore a theory of the "true $\left[\right.$ wahrhafte $\left.^{36}\right]$ phenomenon" in contradistinction with the misinterpretation that makes of it a mere appearance, Schein. And it is the task of phenomenology to "present", in their true light, the phenomena and to "deduce" ${ }^{37}$ them correctly; that is, in consideration of the results of the first part: reached through the insight into the absolute. In this regard, Jean-Christophe Goddard is certainly right when he argues that this Wissenschaftslehre gives back to the phenomenal world its legitimate claim to truth. ${ }^{38}$ At the end of his lectures, Fichte enumerates the different strata of this phenomenal world. He mentions themes that are so many domains for the concrete elaboration of his Wissenschaftslehre, namely 1- the principle of sensibility (our belief in nature), 2- the principle of legality, 3- the standpoint of morality and 4- the standpoint of religion.

When we endeavour to search for the sources of Fichte's concept of phenomenology in 1804, we are facing a problem similar to the one the commentators of Hegel are confronted with

\footnotetext{
${ }^{34}$ Fichte, WL 1804/II, pp. 142-143.

${ }^{35}$ Fichte, WL 1804/II, p. 157, see also p. 147.

${ }^{36}$ Fichte, WL 1804/II, p. 160.

${ }^{37}$ Fichte, WL 1804/II, pp. 89-90, 200.

${ }^{38}$ Jean-Christophe Goddard, Fichte (1801-1813), p. 47.
} 
when they investigate the sources of the title of the Phenomenology of Spirit. Since they find no clear indication on Hegel's part, they are obliged to draw parallels with Lambert, Kant, Reinhold and Fichte, although, here again, they do not know if Hegel had read more than the first of Reinhold's Beyträge, which was one of the main targets of the Differenzschrift, and although there is very little chance, on the other hand, that Hegel could have had access to the detailed content of Fichte's Berlin lectures of $1804^{39}$. Therefore, since in Fichte's case the evidence concerning possible influences has also been absent, we might ask ourselves what Fichte could have retained from the authors that we have taken into consideration. Aside from the various semantic elements on which I have focused until now, together with certain formal analogies, what in these authors can be regarded as relevant from the point of view of Fichte's philosophy?

Apart from the fact that they place appearance at the center of phenomenology, it is not clear at first glance in what way Fichte could have profited from of the concrete developments of the fourth part of the Neues Organon. Effectively, Lambert deals mainly with a Schein that is empirical, namely the "sensible", the "psychological" and the "moral" appearance, ${ }^{40}$ in which case the attention is primarily centered on the interference of sensations and passions in moral life. If there is, however, one thesis of Lambert that remains valid for Fichte, it is likely to be found in what Lambert calls the "method of the astronomers". For example, in a letter dated from October 13, 1770, Lambert urges Kant to adopt in metaphysics the same attitude as the astronomers; that is, to make the assumption from the start that "everything" is mere appearance (Schein), and then try to distinguish what is illusion and what is reality. This means that the reality behind appearances must be sought out and exposed with the help of laws. This could be brought together with Fichte's conclusion in the phenomenology, according to which every phenomenon, having no separate existence of its own, as long as it has not been interpreted as part of the manifestation of the absolute, is nothing more than a mere Schein.

In the case of Kant, as we have seen, the strict distinction established in the Critique of Pure Reason between Erscheinung and Schein is only a methodological clarification. As soon as we consider the content of the Critique and in particular the goal of the Transcendental Dialectic, we recognize the usefulness of this distinction. In fact, it is in the Prolegomena (1783) that Kant

\footnotetext{
${ }^{39}$ See the introduction of W. Bonsiepen to his edition of Hegel's Phänomenologie des Geistes (Hamburg : Meiner, 1988), p. XVI.

${ }^{40}$ Lambert, Neues Organon, Philos. Schriften II, pp. 237, 276, 300.
} 
is most explicit about the need to distinguish, but also, in a second step, to bring together phenomenon and appearance, in order to refute the claims of dogmatic metaphysics. In a remark following $\S 13$, he argues that the world of phenomena has to be clearly established -- as the realm of truth -- if one is to be in a position to identify metaphysical appearance ${ }^{41}$ : Erscheinung and Schein are here presented in their complementary functions. But already in 1781 the first Critique had no doubt made use of this distinction, for example when he claimed that the source of the transcendental Antinomy lies in the fact that phenomena are taken for things in themselves, thereby giving rise to dialectical appearance. And the same can be said of the two other ideas of reason: the origin of the illusions of the omnitudo realitatis (God) and of the immortal soul are also anchored in the phenomenal world. So this means that Fichte could already have learnt from Kant that metaphysical Schein necessarily presupposes a world of Erscheinungen.

But the distance between the two thinkers is still enormous, and this is true even though Fichte claimed in 1804 that Kant's transcendental philosophy is the only philosophical discourse with which he is ready to associate his own enterprise. The gap between them, however, comes to the fore in the central line of criticism that Fichte develops against Kant in the 1804 Wissenschaftslehre. The criticism amounts to saying that Kant as a philosopher cannot surmount mere factuality. This term must be understood, as we know, as the opposite of genesis. For instance, Kant's goal in the third Critique is to find the "root" common to nature and freedom, to "empirical experience" and the "moral world", each of them considered as an absolute. ${ }^{42}$ But in the end, Kant is unable to attain this common ground. The unity of the system is for him something certain, but it remains mere "factual" evidence, whereas it should have been "genetic". This means that Fichte has doubts as to Kant's capacities as a genetic philosopher. And this failing has consequences for Kant's ability to deal with Schein in general.

This argument is developed at the beginning of the 1804 Wissenschaftslehre, and since it is part of Fichte's methodological remarks concerning the problem of "attention", Kant is not mentioned by name. But the same criticism had already been explicitly directed at him in the Second Introduction to the Doctrine of Science (1797). The argument in Section 10 takes the form of the following question: How can Kant still claim to be in danger of a relapse into transcendental appearance after having philosophically explained its origin? This led Fichte to

\footnotetext{
${ }^{41}$ Kant, Prolegomena, Ak. IV: 292.

${ }^{42}$ Fichte, WL 1804/II, p. 28. See also pp. 20, 38, 88.
} 
think that Kant, when writing the Critique of Pure Reason, could not be entirely "convinced" by his own philosophy, since it is utterly absurd to constantly fear a reversion into the delusion of metaphysics, when one has deciphered all of its workings ${ }^{43}$. This only confirms Fichte's view according to which Kant remains at the surface of things: that he remains a philosopher of factuality, and this precisely because he is not enough of a genetic thinker. As such Kant does not provide us with an extensive theory of the relation between Erscheinung and Schein, with an authentic phenomenology.

Concerning Reinhold, finally, we have come to the conclusion that it is impossible to know exactly what Fichte could have taken from him for his own philosophy. The three parallels already pointed out between the two thinkers are only analogies and they do not allow us to conclude anything with certainty. As I have said, the references to Reinhold in the Wissenschaftslehre of 1804 are all critical. One of these critical remarks has to do with the fact that Reinhold in his exposition of the first part of rational realism "does not refer" to consciousness. He develops the doctrine of pure thought, the doctrine of thinking as thinking, without being able to assign a proper place to consciousness. It is as though Reinhold experienced difficulties in articulating his conception of the absolute, of the thinking of the originary essence (Urwesen) with consciousness. But the fact of the matter is that this is a very difficult question indeed, a question that Fichte is also confronted with, and that he himself is led to solve through recourse to pure factuality. As Miklos Vetö aptly remarks, Fichte's Wissenschaftslehre succeeds at disclosing the genesis of every phenomena, but in the end it fails to articulate the genesis of consciousness itself $f^{44}$. For Fichte, consciousness must be accepted as a fact, attributed to a proiectio per hiatum stemming from being itself. And until the end Fichte asks himself how he should conceive of the "hiatus" in question, so that it might not be considered a hiatus irrationalis. ${ }^{45}$ Facing such a difficult problem for himself, Fichte could have adopted a more conciliatory attitude toward Reinhold, or he could at least have entered into a more extensive discussion with the developments of the Beyträge.

\footnotetext{
${ }^{43}$ Fichte, Zweite Einleitung in die Wissenschaftslehre, GA I/4: 264.

${ }^{44}$ Miklos Vetö, Fichte. De l'Action à l'Image, p. 107.

${ }^{45}$ Fichte, WL 1804/II, p. 217.
} 